\title{
ELECTROLYTE AND WATER EXCRETION IN ARTERIAL HYPERTENSION. I. STUDIES IN NON-MEDICALLY TREATED SUBJECTS WITH ESSENTIAL HYPERTENSION 1
}

\author{
BY WILLIAM HOLLANDER 2 AND WALTER E. JUDSON 3 \\ (From the Robert Dawson Evans Memorial, Department of Clinical Research and Preventive \\ Medicine, Massachusetts Memorial Hospitals, and the Department of Medicine, \\ Boston University School of Medicine, Boston, Mass.)
}

(Submitted for publication April 3, 1957; accepted June 21, 1957)

In a preliminary investigation it was reported that abnormally high rates of sodium excretion followed the infusion of hypertonic saline in untreated patients with essential hypertension (1). Furthermore, it was noted that several oral drugs commonly employed in the treatment of hypertension usually modified this pattern of renal sodium excretion. The present report describes further work on sodium excretion in hypertensive patients and in general agrees with previous reports of other authors $(2,3)$. In addition, it describes studies made in an attempt to clarify the disturbance of sodium excretion in hypertension and its relationship to renal function, renal hemodynamics, salt intake, and splanchnic sympathetic activity.

\section{MATERIAL AND METHODS}

The eight normotensive subjects in Group I had no history of hypertension and were considered normal with the exception of D. R. who had bronchial asthma in remission at the time of the study, and M. G. who had asymptomatic chronic pyelonephritis.

The nine subjects in Group II were known to have essential hypertension for at least five years. They were all compensated and had no history of congestive heart failure. However, five subjects in Group II had hypertensive heart disease, with an enlarged left ventricle as indicated by the electrocardiogram and chest roentgenogram.

The eight subjects in Group III, who also had essential hypertension without cardiac decompensation, had been surgically treated more than two years before the study with a bilateral thoracolumbar sympathectomy. Patient T. S., in addition, had had a total bilateral adrenalectomy for malignant hypertension. Four patients of the group had definite hypertensive heart disease.

1 This investigation was supported in part by a grant from the National Heart Institute of the National Institutes of Health, United States Public Health Service.

2 Special Research Fellow of the National Heart Institute, United States Public Health Service.

8 Present address: Indiana University Medical Center, Indianapolis, Indiana.
Dietary intake of salt was not restricted. All hypertensive patients had been without antihypertensive drug treatment for at least three months prior to the study. The average surface areas of patients in the three groups were comparable.

All subjects were studied without sedative medication in the morning, in the post-absorptive state while lying supine. Throughout the study the subjects drank $100 \mathrm{ml}$. of water every half-hour. Urine was collected through an indwelling bladder (Foley) catheter. At the end of each collection the bladder was washed out with $20 \mathrm{ml}$. of distilled water and was then completely evacuated with air. After standard priming doses, a sustaining infusion containing inulin (3.3 per cent) and para-aminohippurate ( 1 per cent) in 3.5 per cent glucose in water was started and given at the rate of $1.2 \mathrm{ml}$. per minute by means of calibrated drip. Every 20 minutes arterial blood samples were obtained for the determination of inulin, para-aminohippuric acid, sodium, potassium and hematocrit. Following the control period which consisted of three to four urine collections, each one being for 10 to 15 minutes, $300 \mathrm{ml}$. of 5 per cent sodium chloride was administered intravenously at the rate of 10 to $12 \mathrm{ml}$. per minute. At the end of the infusion a urine collection designated as "5 per cent $\mathrm{NaCl}$ " was made. Thereafter, at least three urine collections were obtained in the "recovery" period at intervals of 15 minutes. In a few subjects following the "recovery" period, Pitressine was injected intravenously in a single dose of 40 to 100 milliunits. After the injection three more urine collections were made in the "Pitressino" period at intervals of 15 minutes.

Blood and urine concentrations of para-aminohippuric acid were measured by the method of Goldring and Chasis (4), and inulin was determined by the method of Roe, Epstein, and Goldstein (5). Serum and urinary sodium and potassium were determined by the internal standard flame photometer (lithium standard). The hematocrit was determined in Wintrobe tubes. Measurements of brachial arterial pressure were obtained with an electromanometer (Sanborn) and recorded by direct-writing oscillograph.

\section{RESULTS}

The renal responses to intravenous 5 per cent sodium chloride in the normotensive and hypertensive groups are summarized in Table $I$. The 
statistical analysis of the responses are given in Table II.

\section{$P A H$ clearance (renal plasma flow)}

The control renal plasma flows in the hypertensive groups were not significantly different from those in the normotensive group. All three groups had significant increases in renal plasma flow during the infusion of 5 per cent sodium chloride. In only the non-splanchnicectomized hypertensive group were the increases significantly prolonged into the recovery period. Otherwise the changes in renal plasma flow during and following the saline infusion were not significantly different in the three groups.

\section{Inulin clearance (glomerular filtration rate)}

The glomerular filtration rates at rest did not differ significantly between the hypertensive and normotensive groups. During and following the saline infusion, the splanchnicectomized hypertensive group like the normotensive group had no significant increases in glomerular filtration rate although the untreated hypertensive group had small but significant increases in this function. Otherwise, the changes in glomerular filtration rate caused by the hypertonic saline were not significantly different in the groups.

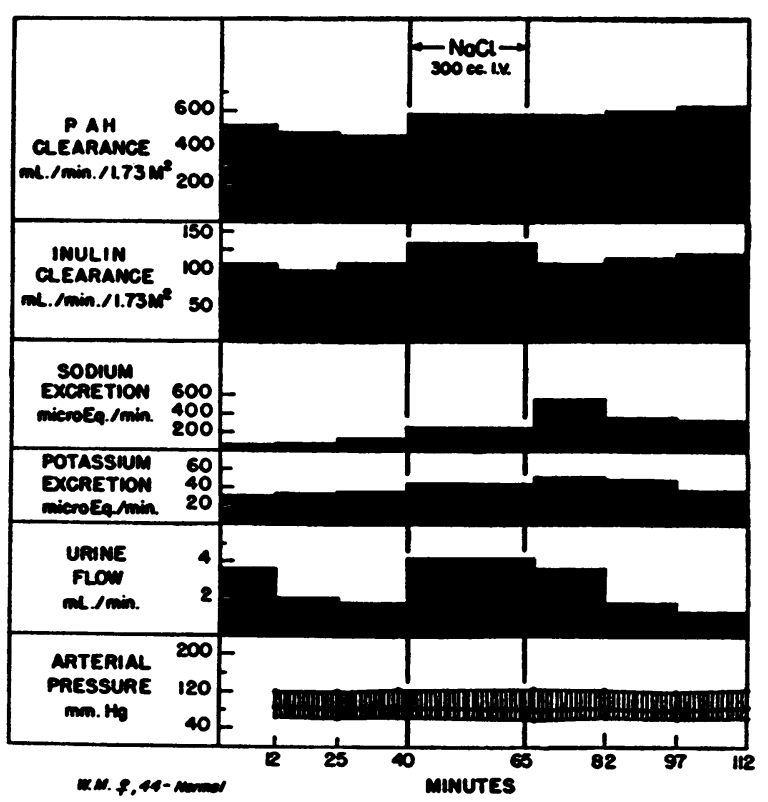

Fig. 1. Renal Responses to Intratenous Hypertontc Saline in a Normotensive INDIVIDUal

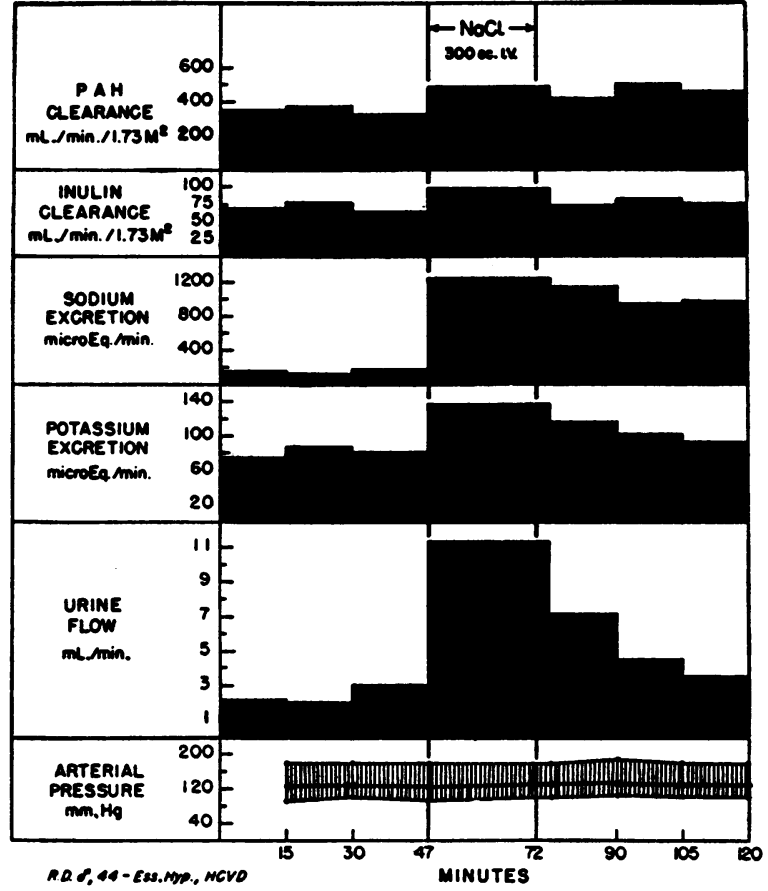

Fig. 2. Renal Responses to Intravenous Hypertonic Saline in a Subject with Essential HyperTENSION

\section{Sodium excretion}

The control sodium excretion in the untreated hypertensive group but not in the splanchnicectomized hypertensive group was significantly higher than in the normotensive group. Although all three groups showed significant increases in sodium excretion during and following the infusion of 5 per cent sodium chloride, the increases were significantly greater in the hypertensive groups than in the normotensive group (Figures 1,2 and 3 ). Included in the splanchnicectomized hypertensive group was an adrenalectomized subject who also had an abnormally high rate of sodium excretion after the saline infusion (Figure 4). The mean increase in sodium excretion in the splanchnicectomized hypertensive group was not as great as in the non-splanchnicectomized hypertensive group.

\section{Ratio of excreted sodium to filtered sodium ( $E / F$} sodium)

The calculated ratio of excreted sodium to filtered sodium (E/F sodium) both before and after 
TABLE I

Renal excretion of hypertonic saline in normotensive individuals (Group I)

\begin{tabular}{|c|c|c|c|c|c|c|c|c|c|c|c|}
\hline \multicolumn{2}{|c|}{ Patient } & \multirow[b]{2}{*}{ Diagnosisf } & \multirow[b]{2}{*}{ Procedure } & \multirow[b]{2}{*}{ CPAH } & \multirow[b]{2}{*}{ Crs } & \multirow[b]{2}{*}{ UV } & \multirow[b]{2}{*}{$U_{\mathrm{Na}} \mathrm{V}$} & \multirow[b]{2}{*}{$U_{K V}$} & \multirow{2}{*}{$\frac{\mathrm{E}}{\mathrm{F}} \mathrm{Na}$} & \multirow{2}{*}{$\frac{E}{F} \mathbf{K t}$} & \multirow{2}{*}{$\begin{array}{c}\text { Hema- } \\
\text { tocrit } \\
\text { (arterial) }\end{array}$} \\
\hline Age & Sex & & & & & & & & & & \\
\hline \multirow{2}{*}{\multicolumn{2}{|c|}{$31^{\text {V. B. }}$}} & & & ml.1min./2./ & $\operatorname{ml.jmin.1}$ & ml./min. & $\begin{array}{l}\text { MicroEq.l } \\
\text { min. }\end{array}$ & $\begin{array}{l}\text { MicroEq.I } \\
\text { min. }\end{array}$ & $\%$ & $\%$ & $\%$ \\
\hline & & Normal & $\begin{array}{l}\text { Control } \\
5 \% \mathrm{NaCl} \\
\text { Recovery }\end{array}$ & $\begin{array}{l}447 \\
519 \\
572\end{array}$ & $\begin{array}{l}90 \\
97 \\
90\end{array}$ & $\begin{array}{l}2.9 \\
2.7 \\
1.5\end{array}$ & $\begin{array}{l}155 \\
260 \\
366\end{array}$ & $\begin{array}{l}90 \\
88 \\
81\end{array}$ & $\begin{array}{l}1.2 \\
1.8 \\
2.7\end{array}$ & $\begin{array}{l}25.6 \\
22.0 \\
23.7\end{array}$ & $\begin{array}{l}42.0 \\
38.0 \\
38.4\end{array}$ \\
\hline \multicolumn{2}{|c|}{${ }_{27}^{\text {J.M. M. F }}$} & Normal & $\begin{array}{l}\text { Control } \\
5 \% \mathrm{NaCl} \\
5 \mathrm{Naviry}\end{array}$ & & $\begin{array}{l}106 \\
100 \\
106\end{array}$ & $\begin{array}{l}3.4 \\
2.0 \\
1.5\end{array}$ & $\begin{array}{r}84 \\
184 \\
243\end{array}$ & $\begin{array}{l}233 \\
158 \\
223\end{array}$ & $\begin{array}{l}0.5 \\
1.2 \\
1.5\end{array}$ & & $\begin{array}{l}42.5 \\
37.8 \\
38.2\end{array}$ \\
\hline \multicolumn{2}{|c|}{${ }_{52}$ D. R. $M$} & $\begin{array}{l}\text { Bronchial } \\
\text { asthma }\end{array}$ & $\begin{array}{l}\text { Control } \\
\text { 5\% NaCl } \\
\text { Recovery }\end{array}$ & $\begin{array}{l}347 \\
407 \\
367\end{array}$ & $\begin{array}{r}96 \\
123 \\
126\end{array}$ & $\begin{array}{l}6.9 \\
7.6 \\
1.7\end{array}$ & $\begin{array}{l}188 \\
391 \\
328\end{array}$ & $\begin{array}{l}58 \\
78 \\
41\end{array}$ & $\begin{array}{l}1.4 \\
2.2 \\
1.8\end{array}$ & $\begin{array}{r}13.4 \\
14.1 \\
7.2\end{array}$ & $\begin{array}{l}54.9 \\
50.1 \\
51.9\end{array}$ \\
\hline \multicolumn{2}{|c|}{$32^{\text {W. P. F }}$} & Normal & $\begin{array}{l}\text { Control } \\
5 \% \mathrm{NaCl} \\
5 \% \text { inery }\end{array}$ & $\begin{array}{l}498 \\
561 \\
504\end{array}$ & $\begin{array}{r}98 \\
109 \\
100\end{array}$ & $\begin{array}{l}2.0 \\
2.8 \\
4.1\end{array}$ & $\begin{array}{l}213 \\
526 \\
599\end{array}$ & $\begin{array}{l}65 \\
54 \\
40\end{array}$ & $\begin{array}{l}1.6 \\
3.4 \\
4.4\end{array}$ & $\begin{array}{l}15.9 \\
13.3 \\
10.0\end{array}$ & $\begin{array}{l}42.2 \\
38.4\end{array}$ \\
\hline \multicolumn{2}{|c|}{$44^{\text {W. M. }}$ F } & Normal & $\begin{array}{l}\text { Control } \\
\mathbf{5 \% ~} \mathrm{NaCl} \\
\text { Recovery }\end{array}$ & $\begin{array}{l}481 \\
575 \\
598\end{array}$ & $\begin{array}{l}102 \\
130 \\
112\end{array}$ & $\begin{array}{l}2.5 \\
4.2 \\
2.3\end{array}$ & $\begin{array}{r}98 \\
244 \\
425\end{array}$ & $\begin{array}{l}33 \\
43 \\
46\end{array}$ & $\begin{array}{l}0.7 \\
1.3\end{array}$ & $\begin{array}{r}8.1 \\
8.5 \\
10.5\end{array}$ & $\begin{array}{l}36.3 \\
32.3 \\
33.9\end{array}$ \\
\hline \multicolumn{2}{|c|}{${ }_{47^{\mathrm{J}}}^{\mathrm{J} K .} \mathrm{M}$} & Normal & $\begin{array}{l}\text { Control } \\
5 \% \mathrm{NaCl} \\
\text { Recovery }\end{array}$ & $\begin{array}{l}505 \\
579 \\
451\end{array}$ & $\begin{array}{l}98 \\
99 \\
94\end{array}$ & $\begin{array}{l}6.3 \\
7.9 \\
1.1\end{array}$ & $\begin{array}{r}60 \\
218 \\
376\end{array}$ & $\begin{array}{l}84 \\
94 \\
61\end{array}$ & $\begin{array}{l}0.5 \\
1.5 \\
1.1\end{array}$ & $\begin{array}{l}24.6 \\
26.4 \\
21.3\end{array}$ & $\begin{array}{l}46.0 \\
41.5 \\
41.7\end{array}$ \\
\hline \multicolumn{2}{|c|}{$62^{M . G .} \mathrm{F}$} & $\begin{array}{l}\text { Chronic } \\
\text { pyelo- } \\
\text { nephritis }\end{array}$ & $\begin{array}{l}\text { Control } \\
5 \% \mathrm{NaCl} \\
\text { Recovery }\end{array}$ & $\begin{array}{l}182 \\
211 \\
234\end{array}$ & $\begin{array}{l}54 \\
57 \\
56\end{array}$ & $\begin{array}{l}2.6 \\
3.3 \\
1.8\end{array}$ & $\begin{array}{r}81 \\
319 \\
306\end{array}$ & $\begin{array}{l}43 \\
60 \\
59\end{array}$ & $\begin{array}{l}1.6 \\
3.9 \\
3.8\end{array}$ & $\begin{array}{l}18.1 \\
23.9 \\
24.0\end{array}$ & $\begin{array}{l}48.4 \\
43.0 \\
44.4\end{array}$ \\
\hline \multicolumn{2}{|c|}{$38^{\text {C. J. }} \mathrm{F}$} & Normal & $\begin{array}{l}\text { Control } \\
5 \% \mathrm{NaCl} \\
\text { Recovery }\end{array}$ & $\begin{array}{l}632 \\
598 \\
623\end{array}$ & $\begin{array}{r}101 \\
91 \\
102\end{array}$ & $\begin{array}{r}11.3 \\
12.5 \\
1.3\end{array}$ & $\begin{array}{l}101 \\
168 \\
275\end{array}$ & $\begin{array}{l}90 \\
52 \\
41\end{array}$ & $\begin{array}{l}0.7 \\
1.1\end{array}$ & $\begin{array}{l}22.6 \\
10.0\end{array}$ & $\begin{array}{r}42.7 \\
40.6\end{array}$ \\
\hline \multicolumn{12}{|c|}{ Renal excretion of hypertonic saline in individuals with essential hypertension (Group II) } \\
\hline $35^{K}$ & $\mathbf{M}$ & Ess. hyp. & $\begin{array}{l}\text { Control } \\
5 \% \mathrm{NaCl} \\
\text { Recovery }\end{array}$ & $\begin{array}{l}565 \\
744 \\
789\end{array}$ & $\begin{array}{l}126 \\
130 \\
135\end{array}$ & $\begin{array}{r}6.3 \\
12.8 \\
7.7\end{array}$ & $\begin{array}{r}617 \\
2,290 \\
1,561\end{array}$ & $\begin{array}{r}145 \\
137 \\
152 \\
\end{array}$ & $\begin{array}{r}3.5 \\
12.1 \\
7.9\end{array}$ & $\begin{array}{l}23.0 \\
20.3 \\
21.6\end{array}$ & $\begin{array}{l}46.5 \\
42.6 \\
43.2\end{array}$ \\
\hline $4_{44^{R}}$ & $M$ & $\begin{array}{l}\text { Ess. hyp. } \\
\text { H.C.V.D. }\end{array}$ & $\begin{array}{l}\text { Control } \\
5 \% \mathrm{NaCl} \\
\text { Recovery }\end{array}$ & $\begin{array}{l}351 \\
484 \\
462\end{array}$ & $\begin{array}{l}73 \\
99 \\
79\end{array}$ & $\begin{array}{r}2.6 \\
11.4 \\
5.0\end{array}$ & $\begin{array}{l}152 \\
1,258 \\
1,014\end{array}$ & $\begin{array}{r}87 \\
137 \\
114\end{array}$ & $\begin{array}{l}1.4 \\
8.7 \\
8.8\end{array}$ & $\begin{array}{l}30.0 \\
38.5 \\
36.1\end{array}$ & $\begin{array}{l}44.3 \\
40.2 \\
39.9\end{array}$ \\
\hline $36^{\mathrm{I}}$ & $F$ & $\begin{array}{l}\text { Ess. hyp. } \\
\text { H.C.V.D. }\end{array}$ & $\begin{array}{l}\text { Control } \\
5 \% \mathrm{NaCl} \\
\text { Recovery }\end{array}$ & $\begin{array}{l}309 \\
303 \\
355\end{array}$ & $\begin{array}{l}81 \\
80 \\
85\end{array}$ & $\begin{array}{r}12.4 \\
10.5 \\
5.9\end{array}$ & $\begin{array}{r}601 \\
706 \\
1,131\end{array}$ & $\begin{array}{l}77 \\
68 \\
76\end{array}$ & $\begin{array}{l}5.5 \\
6.2 \\
9.5\end{array}$ & $\begin{array}{l}23.8 \\
21.3 \\
22.3\end{array}$ & $\begin{array}{l}40.3 \\
34.9 \\
37.4\end{array}$ \\
\hline & $F$ & Ess. hyp. & $\begin{array}{l}\text { Control } \\
\mathbf{5 \%} \mathrm{NaCl} \\
\text { Recovery }\end{array}$ & $\begin{array}{l}390 \\
530 \\
468\end{array}$ & $\begin{array}{r}91 \\
108 \\
96\end{array}$ & $\begin{array}{l}87 \\
8.0 \\
7.7\end{array}$ & $\begin{array}{r}723 \\
1,202 \\
1,661\end{array}$ & $\begin{array}{l}74 \\
91 \\
91\end{array}$ & $\begin{array}{r}5.6 \\
7.2 \\
11.5\end{array}$ & $\begin{array}{l}21.4 \\
22.2 \\
24.9\end{array}$ & $\begin{array}{l}39.6 \\
35.5 \\
37.5\end{array}$ \\
\hline
\end{tabular}

* $\frac{E}{\mathrm{~F}} \mathrm{Na}=\frac{\text { sodium excreted }}{\text { sodium filtered }}$.

$\dagger \frac{E}{F} K=\frac{\text { potassium excreted }}{\text { potassium filtered }}$.

$\ddagger$ Ess. hyp. = Essential hypertension.

H.C.V.D. = Hypertensive cardiovascular disease.

$\S$ Previously adrenalectomized. 
TABLE I-Continued

\begin{tabular}{|c|c|c|c|c|c|c|c|c|c|c|c|}
\hline \multicolumn{2}{|c|}{ Patient } & \multirow[b]{2}{*}{ Diagnosisł } & \multirow[b]{2}{*}{ Procedure } & \multirow[b]{2}{*}{$\mathrm{C}_{\mathrm{PAH}}$} & \multirow[b]{2}{*}{ CIn } & \multirow[b]{2}{*}{ UV } & \multirow[b]{2}{*}{$\mathrm{UNaV}_{\mathrm{Na}}$} & \multirow[b]{2}{*}{$U_{\mathbf{K} V}$} & \multirow{2}{*}{$\frac{\mathrm{E}}{\mathrm{F}} \mathrm{Na}^{*}$} & \multirow{2}{*}{$\frac{E}{F} \mathbf{K} \dagger$} & \multirow{2}{*}{$\begin{array}{c}\text { Hema- } \\
\text { tocrit } \\
\text { (arterial) }\end{array}$} \\
\hline Age & Sex & & & & & & & & & & \\
\hline & & & & $\operatorname{ml}_{1.73 \mathrm{Min}} \mathrm{Mi}^{2}$ & $\operatorname{ml}_{1.73 M^{2}}$ & ml./min. & $\underset{\substack{\text { Min. } \\
\text { min. }}}{\text { M. }}$ & $\underset{\text { min. }}{\operatorname{MicroE} . \mid}$ & $\%$ & $\%$ & $\%$ \\
\hline & $\mathbf{M}$ & $\begin{array}{l}\text { Ess. hyp. } \\
\text { H.C.V.D. }\end{array}$ & $\begin{array}{l}\text { Control } \\
5 \% \mathrm{NaCl} \\
\text { Recovery }\end{array}$ & $\begin{array}{l}467 \\
659 \\
624\end{array}$ & $\begin{array}{l}131 \\
142 \\
133\end{array}$ & $\begin{array}{r}4.8 \\
13.0 \\
12.2\end{array}$ & $\begin{array}{r}765 \\
2,387 \\
2,364\end{array}$ & $\begin{array}{l}104 \\
211 \\
163\end{array}$ & $\begin{array}{r}4.5 \\
11.3 \\
12.1\end{array}$ & $\begin{array}{l}22.6 \\
42.4 \\
35.8\end{array}$ & $\begin{array}{l}43.3 \\
39.8 \\
41.0\end{array}$ \\
\hline & $F$ & $\begin{array}{l}\text { Ess. hyp. } \\
\text { H.C.V.D. }\end{array}$ & $\begin{array}{l}\text { Control } \\
\mathbf{5 \%} \mathrm{NaCl} \\
\text { Recovery }\end{array}$ & $\begin{array}{l}458 \\
643 \\
625\end{array}$ & $\begin{array}{l}106 \\
128 \\
132\end{array}$ & $\begin{array}{l}8.0 \\
8.2 \\
9.3\end{array}$ & $\begin{array}{r}250 \\
1,340 \\
1,726\end{array}$ & $\begin{array}{r}78 \\
143 \\
128\end{array}$ & $\begin{array}{l}1.6 \\
7.0 \\
8.7\end{array}$ & $\begin{array}{l}17.4 \\
28.5 \\
22.4\end{array}$ & $\begin{array}{l}38.3 \\
38.0\end{array}$ \\
\hline & $\mathbf{M}$ & $\begin{array}{l}\text { Ess. hyp. } \\
\text { H.C.V.D. }\end{array}$ & $\begin{array}{l}\text { Control } \\
\mathbf{5 \% ~} \mathrm{NaCl} \\
\text { Recovery }\end{array}$ & $\begin{array}{l}322 \\
338 \\
320\end{array}$ & $\begin{array}{l}79 \\
79 \\
85\end{array}$ & $\begin{array}{l}9.1 \\
8.0 \\
4.1\end{array}$ & $\begin{array}{l}141 \\
975 \\
802\end{array}$ & $\begin{array}{r}121 \\
139 \\
80\end{array}$ & $\begin{array}{l}1.2 \\
8.0 \\
6.5\end{array}$ & $\begin{array}{l}40.3 \\
51.7 \\
26.1\end{array}$ & $\begin{array}{l}40.1 \\
37.8\end{array}$ \\
\hline & $M$ & Ess. hyp. & $\begin{array}{l}\text { Control } \\
5 \% \text { NaCl } \\
\text { Recovery } \\
\text { Pitressin @ } \\
40 \text { milliunits }\end{array}$ & $\begin{array}{l}443 \\
518 \\
464 \\
494\end{array}$ & $\begin{array}{l}127 \\
148 \\
131 \\
131\end{array}$ & $\begin{array}{l}8.4 \\
9.6 \\
8.6 \\
7.4\end{array}$ & $\begin{array}{r}216 \\
686 \\
1,276 \\
1,032\end{array}$ & $\begin{array}{l}153 \\
229 \\
214 \\
299\end{array}$ & $\begin{array}{l}1.2 \\
3.1 \\
6.8 \\
5.4\end{array}$ & $\begin{array}{l}31.6 \\
38.7 \\
50.7\end{array}$ & $\begin{array}{l}46.1 \\
44.3 \\
44.7\end{array}$ \\
\hline 50 & $\mathbf{M}$ & $\begin{array}{l}\text { Ess. hyp. } \\
\text { H.C.V.D. }\end{array}$ & $\begin{array}{l}\text { Control } \\
5 \% \mathrm{NaCl} \\
\text { Recovery } \\
\text { Pitressin @ } \\
80 \text { milliunits }\end{array}$ & & $\begin{array}{l}60 \\
78 \\
60 \\
68\end{array}$ & $\begin{array}{r}3.9 \\
14.5 \\
7.3 \\
10.9\end{array}$ & $\begin{array}{r}522 \\
1,682 \\
1,467 \\
1,711\end{array}$ & $\begin{array}{r}72 \\
106 \\
74 \\
98\end{array}$ & $\begin{array}{r}6.2 \\
14.5 \\
16.5 \\
17.2\end{array}$ & $\begin{array}{l}30.0 \\
35.9 \\
30.9 \\
28.7\end{array}$ & $\begin{array}{l}39.5 \\
37.4 \\
38.4\end{array}$ \\
\hline
\end{tabular}

Renal excretion of hypertonic saline in splanchnicectomized individuals with essential hypertension (Group III)

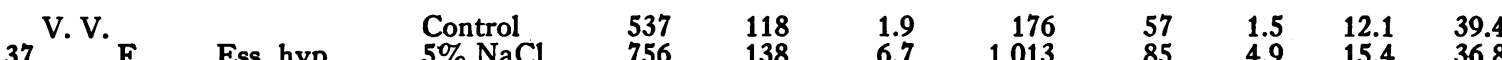

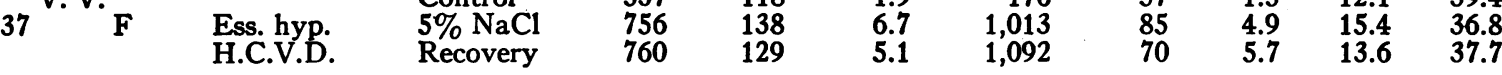

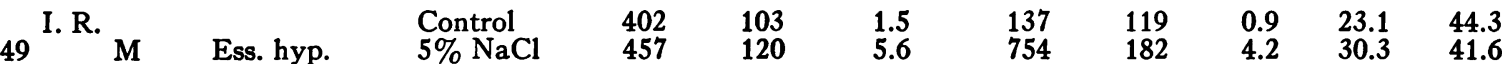

$\begin{array}{llllllllll}\text { Ess. hyp. } & 5 \% \mathrm{NaCl} & 457 & 120 & 5.6 & 754 & 182 & 4.2 & 30.3 & 41.6 \\ \text { H.C.V.D. } & \text { Recovery } & 451 & 118 & 5.3 & 867 & 147 & 5.1 & 25.0 & 41.7\end{array}$

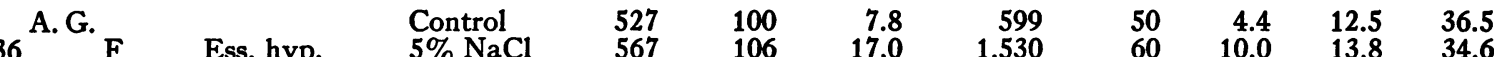

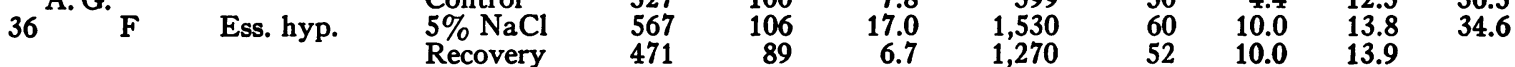

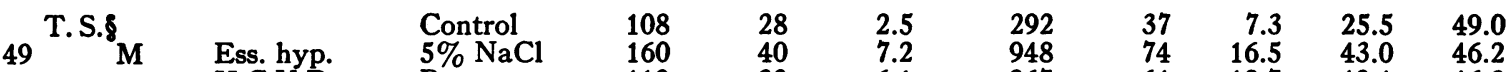

$\begin{array}{llllllllll}\text { H.C.V.D. } & \text { Recovery } & 110 & 33 & 6.1 & 867 & 64 & 18.7 & 42.1 & 46.8\end{array}$

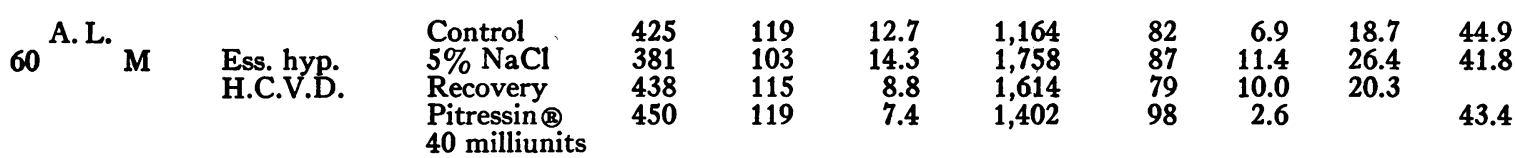

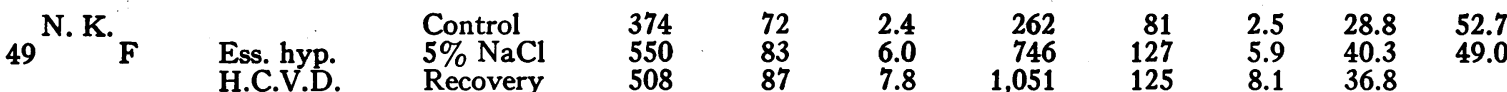

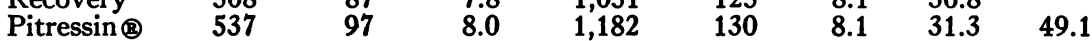

100 milliunits

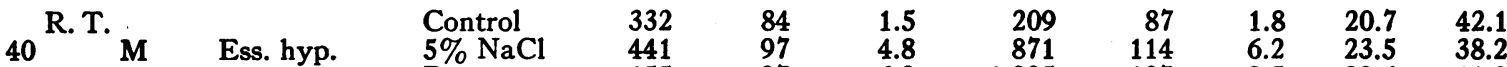

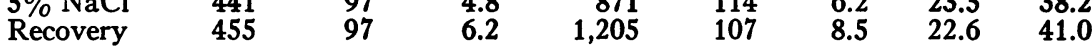

\begin{tabular}{|c|c|c|c|c|c|c|c|c|c|}
\hline${ }_{58}{ }^{\text {N.I. }}$ & Ess. hyp. & $\begin{array}{l}\text { Control } \\
\mathbf{5 \%} \mathrm{NaCl} \\
\text { Recovery }\end{array}$ & $\begin{array}{l}322 \\
395 \\
407\end{array}$ & $\begin{array}{l}83 \\
78 \\
96\end{array}$ & $\begin{array}{l}5.2 \\
5.1 \\
5.9\end{array}$ & $\begin{array}{r}39 \\
848 \\
913\end{array}$ & $\begin{array}{l}32 \\
74 \\
77\end{array}$ & $\begin{array}{l}0.3 \\
7.5 \\
6.6\end{array}$ & $\begin{array}{r}8.8 \\
21.1 \\
17.9\end{array}$ \\
\hline
\end{tabular}


TABLE II

Mean data and statistical analysis

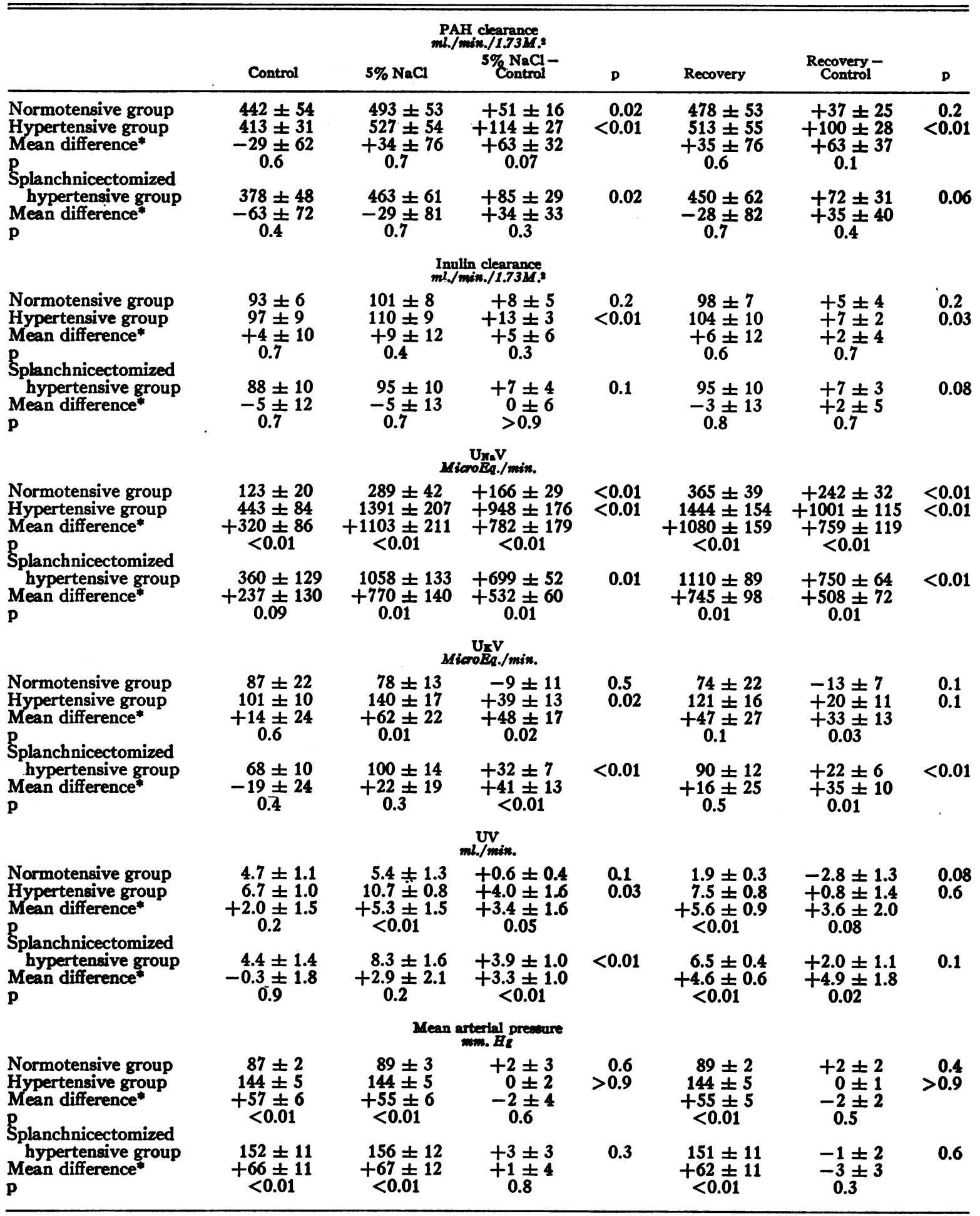

* Refers to the difference between the normotensive and the designated hypertensive group. 


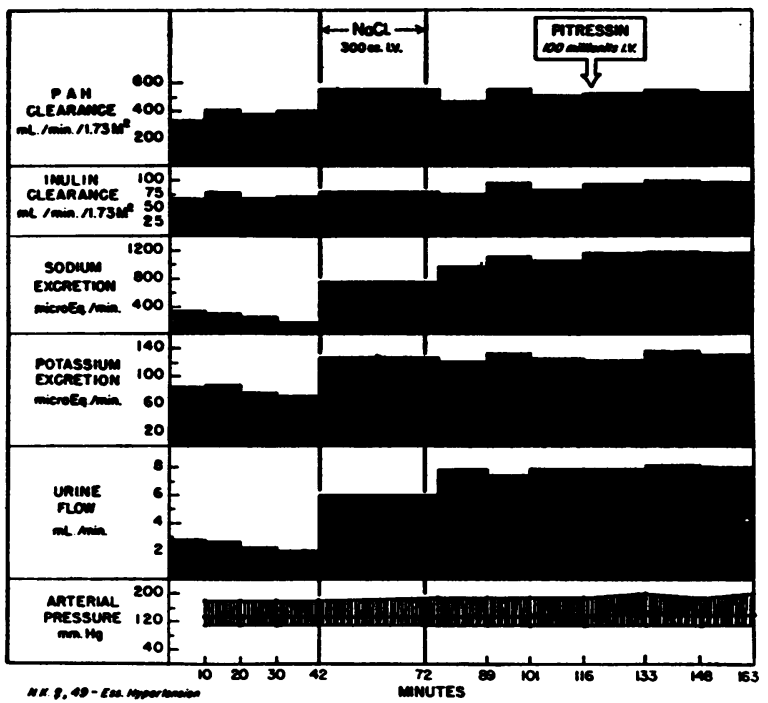

Fig. 3. Renal Responses to Intravenous Hypertonic Saline in Splanchinicectomized Hypertensive SUBJECT

the infusion of saline was significantly higher in the hypertensive groups than in the normotensive group. The increases in this ratio after the infusion, which were significant in all groups, were likewise significantly greater in the hypertensive groups than in the normotensive group.

\section{Correlations of sodium excretion}

In analyzing the groups all together (Table III), sodium excretion before and after the saline infusion was significantly correlated (statistically) with the control arterial pressure. Increases in sodium excretion following intravenous 5 per cent sodium chloride were likewise significantly correlated with changes in renal plasma flow but not with changes in glomerular filtration rate, however. They were not significantly correlated with the control renal plasma flow or with the control glomerular filtration rate.

In analyzing the small groups separately, the control sodium excretion did not show a significant statistical correlation with the control arterial pressure. Increases in sodium excretion produced by the saline infusion also were not correlated with the control arterial pressure, renal plasma flow and glomerular filtration rate, or with the changes in these functions which occurred after the infusion of saline.

\section{Potassium excretion}

The control excretion of potassium in the hypertensive groups was not significantly different from that in the normotensive group. During and following the infusion of 5 per cent saline, the average potassium excretion in the normotensive group decreased slightly but insignificantly whereas in both hypertensive groups it increased slightly. The latter increases were statistically significant except for those in the untreated hypertensive group during the saline infusion.

\section{Ratio of excreted potassium to filtered potassium ( $E / F$ potassium)}

The calculated ratio of excreted potassium to filtered potassium ( $\mathrm{E} / \mathrm{F}$ potassium) during the control period was significantly higher in the untreated but not in the splanchnicectomized hypertensive group than in the normotensive group. This ratio did not change in the normotensive

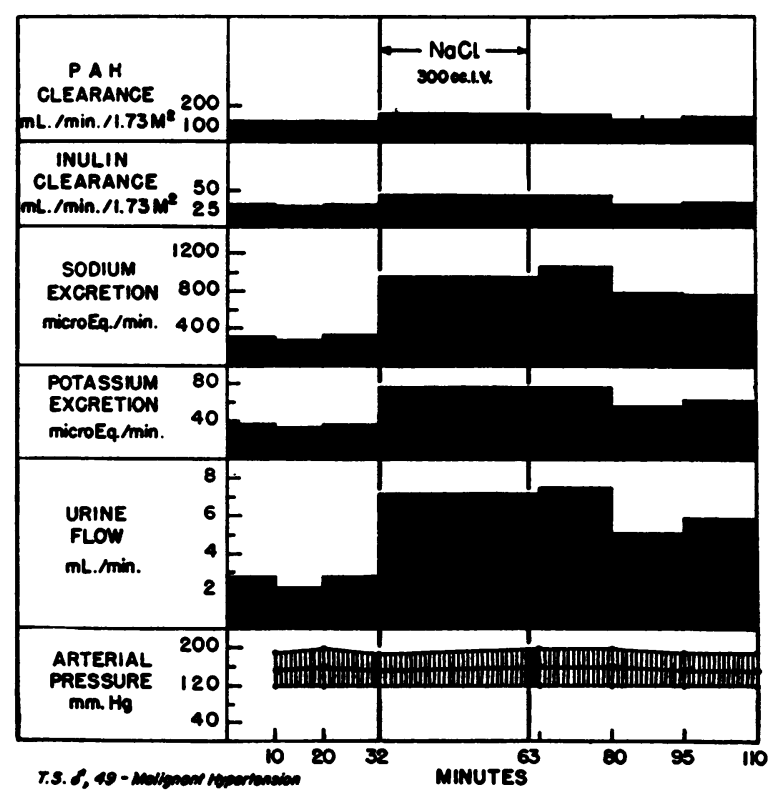

Fig. 4. Renal Responses to Intravenous Hypertonic Saline in a Splanch nicectomized and AdrenaleCtOMIZED HypertensIVE SUbJECT

The subject, who was maintained on $25 \mathrm{mg}$. of oral cortisone and $5 \mathrm{mg}$. of a DOCA linguet daily, had an abnormaly high rate of sodium excretion following the infusion of 5 per cent $\mathrm{NaCl}$ even though the renal plasma flow and glomerular filtration rate were markedly reduced. 
TABLE III

Correlations of sodium excretion

\begin{tabular}{|c|c|c|}
\hline$\Delta \mathrm{Na}$ excretion* correlated with: & $\mathrm{It}$ & $\mathrm{p} \neq$ \\
\hline $\begin{array}{l}\text { Control Na excretion } \\
\text { Control mean B.P. } \\
\text { Control PAH clearance } \\
\text { Control inulin clearance } \\
\Delta \text { PAH clearance* } \\
\Delta \text { Inulin clearance }\end{array}$ & $\begin{array}{l}0.301 \\
0.532 \\
0.165 \\
0.237 \\
0.541 \\
0.226\end{array}$ & $\begin{array}{c}0.2 \\
<0.01 \\
0.5 \\
0.3 \\
<0.01 \\
0.3\end{array}$ \\
\hline $\begin{array}{l}\text { Control Na excretion correlated } \\
\text { with control mean B.P. }\end{array}$ & 0.436 & 0.03 \\
\hline
\end{tabular}

* Changes in function following saline infusion.

$\dagger \mathbf{r}=$ Coefficient of correlation.

$\ddagger \mathrm{p}=$ Probability.

group during the infusion but it increased significantly in the hypertensive groups and was significantly higher in these groups than in the control group. In the recovery period the E/F potassium continued to be significantly higher in the non-splanchnicectomized hypertensive group than in the normotensive group.

\section{Urine flow}

The control urine flow was not significantly different in the groups. During the infusion of saline there was no significant change in urine flow in the normotensive group whereas in the hypertensive groups there was a significant increase in urine excretion. In the recovery period the mean urine flow in the normotensive group decreased but this decrease just lacked statistical significance at the 5 per cent level. In both hypertensive groups, however, the urine flow in the recovery period did not change significantly from the control urine flow and was significantly higher than that in the control group. Pitressin in a single intravenous dose of 40 to 100 milliunits in four hypertensive subjects (W. M., J. W., A. L., and N. K.) did not decrease urine flow in the recovery period suggesting that the sustained flow was due to an osmotic diuresis caused by an increased sodium excretion (Figure 3 ).

\section{Arterial hematocrit}

The arterial hematocrit at rest was not significantly different in the groups. After the infusion of hypertonic saline, it significantly decreased in all three groups. Although the decrease in hematocrit during the infusion was significantly greater in the normotensive than in the hypertensive group, the hematocrit was not significantly different in the groups during and following the infusion.

\section{Arterial pressure}

The mean arterial pressure before and after the saline infusion was significantly higher in the hypertensive groups than in the normotensive group. The changes in mean arterial pressure produced by the infusion were insignificant in all the groups.

\section{Pulse rate}

The average pulse rate at rest and after the saline infusion was not significantly different in the groups and did not change significantly.

\section{Sodium intake and sodium excretion}

In Table IV the effect of altering the sodium content of the diet on the excretion of sodium in response to intravenous 5 per cent sodium chloride is summarized.

During sodium restriction a slight and consistent reduction in weight but not in blood pressure occurred. Associated with the changes in diet and weight, the increases in sodium excretion following the infusion of $300 \mathrm{ml}$. of 5 per cent saline were reduced and were not as great as those found during an unrestricted salt diet. However, sodium excretion was not necessarily reduced to normal by salt restriction in the hypertensive subjects since it remained unequivocally high in at least one (A. L.) of the three subjects. Normotensive subject E. H., who was placed on an 18-gram salt diet, developed slight peripheral edema and a weight gain of six pounds. While on this diet, sodium excretion in response to intravenous hypertonic saline was greater than that observed during a 10-gram salt diet and approached the values found in hypertensive individuals. To determine whether acute increases in body fluid and sodium might augment the excretory response to hypertonic saline in normotensive subjects, isotonic saline was infused at the rate of $22 \mathrm{ml}$. per minute in patients $H$. D. and P. G. prior to the administration of 5 per cent sodium chloride. The prior expansion of the extracellular fluid volume 
with 1,000 to $1,700 \mathrm{ml}$. of saline in both subjects, however, failed to augment sodium excretion in response to intravenous 5 per cent sodium chloride.

\section{DISCUSSION}

In both the normotensive and hypertensive groups the increases in sodium excretion produced by the infusion of hypertonic saline were associated with increases in the calculated load of filtered sodium. Although the latter changes were not measureably different between the groups, the increases in sodium excretion were greater in both the splanchnicectomized and the non-splanchnicectomized hypertensive groups than in the normotensive group. The differences in sodium

TABLE IV

The effect of salt intake on the excretion of sodium

\begin{tabular}{|c|c|c|c|c|c|c|c|c|}
\hline \multicolumn{2}{|c|}{ Patient } & \multirow{2}{*}{$\begin{array}{l}\text { Daily } \\
\text { NaC1 } \\
\text { intake }\end{array}$} & \multirow[b]{2}{*}{ Duration } & \multirow[b]{2}{*}{ Weight } & \multirow{2}{*}{$\begin{array}{c}\text { Blood } \\
\text { pressure }\end{array}$} & \multirow[b]{2}{*}{ Procedure } & \multirow[b]{2}{*}{ U MaV } & \multirow[b]{2}{*}{ uv } \\
\hline Age & Sex & & & & & & & \\
\hline \multirow{2}{*}{\multicolumn{2}{|c|}{$65^{\mathrm{W} . \mathrm{P}}{ }_{\mathrm{M}}$}} & $\begin{array}{c}\text { Gms. } \\
15\end{array}$ & $\begin{array}{l}\text { days } \\
14\end{array}$ & $\begin{array}{l}\text { pounds } \\
162.0\end{array}$ & $\begin{array}{l}m m . H E \\
180 / 110\end{array}$ & $\begin{array}{l}\text { Control } \\
\text { 5\% NaCl }(300 \mathrm{ml} .) \\
\text { Recovery }\end{array}$ & $\begin{array}{c}\text { MicroEq./min. } \\
871 \\
1,127 \\
2,048\end{array}$ & $\begin{array}{c}\text { ml. } / \text { min. } \\
3.7 \\
6.8 \\
10.7\end{array}$ \\
\hline & & 2 & 10 & 160.0 & $170 / 120$ & $\begin{array}{l}\text { Control } \\
5 \% \mathrm{NaCl}(300 \mathrm{ml} .) \\
\text { Recovery }\end{array}$ & $\begin{array}{r}81 \\
221 \\
303\end{array}$ & $\begin{array}{l}2.0 \\
9.3 \\
2.5\end{array}$ \\
\hline \multirow{2}{*}{\multicolumn{2}{|c|}{$45^{\text {A. L. }} \mathrm{M}$}} & 15 & 14 & 158.2 & $250 / 150$ & $\begin{array}{l}\text { Control } \\
5 \% \mathrm{NaCl}(300 \mathrm{ml} .) \\
\text { Recovery }\end{array}$ & $\begin{array}{l}1,064 \\
1,640 \\
1,740\end{array}$ & $\begin{array}{r}6.5 \\
11.2 \\
11.5\end{array}$ \\
\hline & & 2 & 10 & 156.0 & $240 / 145$ & $\begin{array}{l}\text { Control } \\
\text { 5\% NaCl }(300 \mathrm{ml} .) \\
\text { Recovery }\end{array}$ & $\begin{array}{r}40 \\
525 \\
560\end{array}$ & $\begin{array}{l}1.8 \\
4.2 \\
3.5\end{array}$ \\
\hline \multirow{2}{*}{\multicolumn{2}{|c|}{$58^{\text {I. C. }}$ F }} & 10 & 10 & 140.0 & $190 / 110$ & $\begin{array}{l}\text { Control } \\
5 \% \mathrm{NaCl}(300 \mathrm{ml} .) \\
\text { Recovery }\end{array}$ & $\begin{array}{l}242 \\
836 \\
878\end{array}$ & $\begin{array}{l}7.2 \\
8.7 \\
4.9\end{array}$ \\
\hline & & 2 & 10 & 139.0 & $190 / 110$ & $\begin{array}{l}\text { Control } \\
5 \% \mathrm{NaCl}(300 \mathrm{ml} .) \\
\text { Recovery }\end{array}$ & $\begin{array}{l}101 \\
424 \\
343\end{array}$ & $\begin{array}{l}5.9 \\
9.1 \\
2.7\end{array}$ \\
\hline \multirow{3}{*}{\multicolumn{2}{|c|}{${ }_{42}$ E. H. $F$}} & 10 & 9 & 165.5 & $130 / 80$ & $\begin{array}{l}\text { Control } \\
\text { 5\% NaCl }(300 \mathrm{ml} .) \\
\text { Recovery }\end{array}$ & $\begin{array}{l}206 \\
331 \\
326\end{array}$ & $\begin{array}{l}6.7 \\
4.7 \\
1.5\end{array}$ \\
\hline & & 1 & 7 & 162.5 & $130 / 76$ & $\begin{array}{l}\text { Control } \\
5 \% \mathrm{NaCl}(300 \mathrm{ml} .) \\
\text { Recovery }\end{array}$ & $\begin{array}{r}9 \\
24 \\
15\end{array}$ & $\begin{array}{l}4.8 \\
2.7 \\
0.6\end{array}$ \\
\hline & & 18 & 6 & 168.5 & $126 / 74$ & $\begin{array}{l}\text { Control } \\
5 \% \mathrm{NaCl}(300 \mathrm{ml} .) \\
\text { Recovery }\end{array}$ & $\begin{array}{l}235 \\
569 \\
939\end{array}$ & $\begin{array}{r}10.2 \\
9.4 \\
3.1\end{array}$ \\
\hline \multirow{2}{*}{\multicolumn{2}{|c|}{$29^{\text {H. D. F }}$}} & 10 & 5 & 114.5 & $110 / 70$ & $\begin{array}{l}\text { Control } \\
5 \% \mathrm{NaCl}(300 \mathrm{ml} .) \\
\text { Recovery }\end{array}$ & $\begin{array}{l}117 \\
267 \\
442\end{array}$ & $\begin{array}{r}10.1 \\
1.4 \\
2.0\end{array}$ \\
\hline & & 10 & 5 & 114.2 & $110 / 60$ & $\begin{array}{l}\text { Control } \\
0.9 \% \mathrm{NaCl}(1,000 \mathrm{ml} .) \\
5 \% \mathrm{NaCl}(300 \mathrm{ml} .) \\
\text { Recovery }\end{array}$ & $\begin{array}{l}214 \\
152 \\
348 \\
481\end{array}$ & $\begin{array}{l}3.2 \\
4.5 \\
2.9 \\
1.9\end{array}$ \\
\hline \multirow{2}{*}{\multicolumn{2}{|c|}{$22^{\text {P. G. }}$}} & 10. & 7 & 161.5 & $120 / 70$ & $\begin{array}{l}\text { Control } \\
5 \% \mathrm{NaCl}(300 \mathrm{ml} .) \\
\text { Recovery }\end{array}$ & $\begin{array}{l}393 \\
586 \\
589\end{array}$ & $\begin{array}{l}2.9 \\
5.8 \\
1.9\end{array}$ \\
\hline & & 10 & 5 & 162.0 & $118 / 74$ & $\begin{array}{l}\text { Control } \\
0.9 \% \mathrm{NaCl}(1,700 \mathrm{ml} .) \\
5 \% \mathrm{NaCl}(300 \mathrm{ml} .) \\
\text { Recovery }\end{array}$ & $\begin{array}{l}106 \\
166 \\
340 \\
323\end{array}$ & $\begin{array}{l}4.7 \\
4.1 \\
2.7 \\
1.1\end{array}$ \\
\hline
\end{tabular}


excretion therefore appeared to be due to a difference in the renal tubular handling of sodium. Abnormally high rates of sodium excretion in hypertensive individuals have also been reported to occur during mannitol diuresis (6), suggesting that the hypertensive renal response is not a specific one to the elevated serum sodium produced by intravenous 5 per cent sodium chloride but is a non-specific response to an increase in the effective osmotic pressure of the serum.

The lack of a high degree of correlation between the level of the blood pressure and the renal excretory response to a 5 per cent sodium chloride suggests that in addition to the arterial pressure other factors operate to enhance sodium excretion in patients with essential hypertension. Green and Ellis have been able to relate the renal response of hypertensive individuals to an elevated control sodium excretion (7), but in the present study this relationship was not found to be consistent. Control sodium excretion was considerably higher in untreated hypertensive than in normotensive individuals, but in splanchnicectomized hypertensive subjects the control sodium excretion was not significantly different from that of normotensive subjects. Although these findings indicate that an elevated control sodium excretion is not necessary for large increases in sodium excretion to occur after intravenous 5 per cent sodium chloride, the greater increases of sodium excretion in the untreated hypertensive group than in the sympathectomized hypertensive group suggest that it is capable of augmenting the excretory response to hypertonic saline.

By altering the sodium content of the diet in a small number of hypertensive and normotensive individuals, similar directional changes in sodium excretion following the infusion of 5 per cent sodium chloride appeared to result. These observations might be interpreted to indicate that the excretion of sodium is a function of total body sodium. However, the failure to augment sodium excretion by the prior expansion of the extracellular fluid volume with isotonic saline does not support this hypothesis. Luetscher and Curtis' studies (8) suggest that the observed changes in sodium excretion might be the result of an alteration in adrenal cortical activity. Green and Ellis have presented evidence that significant differences in dietary salt intake may actually exist between normotensive and hypertensive individuals and may account for their different excretory responses to intravenous hypertonic saline (7). The findings in the present study, however, indicate that sodium excretion may be abnormal in hypertensive subjects even though their dietary salt intake is normal.

Primary as well as secondary changes in adrenal cortical activity may affect the renal responses to intravenous 5 per cent sodium chloride. Burnett has found that non-hypertensive patients with adrenal cortical insufficiency (Addison's disease) have an impaired excretory response to intravenous hypertonic saline which is partially corrected by steroid treatment (9). On the other hand, Birchall, Tuthill, Jacobs, Trautman, and Findley have observed that in adrenal cortical hyperfunction (Cushing's syndrome) sodium excretion is abnormally high following an infusion of hypertonic saline. By pre-treating a normotensive individual with cortisone, the same investigators were able to augment sodium excretion following intravenous 5 per cent sodium chloride (3). Although the level of adrenal cortical activity appears to be capable of affecting sodium excretion, the observations in an adrenalectomized hypertensive patient, T. S., who had an increased capacity to excrete sodium while on replacement steroid therapy, suggests that the hypertensive response to intravenous 5 per cent sodium chloride does not necessarily depend upon an increase in adrenal function.

\section{SUM MARY}

Both splanchnicectomized and non-splanchnicectomized hypertensive individuals have an increased capacity to excrete sodium as indicated by their excretion of sodium following the infusion of $300 \mathrm{ml}$. of 5 per cent sodium chloride. The capacity to excrete sodium was significantly correlated with the systemic arterial pressure but not with the control sodium excretion, renal plasma flow and glomerular filtration rate. However, the lack of a high degree of correlation between blood pressure and sodium excretion suggests that additional factors operate to enhance sodium excretion in individuals with essential hypertension. Some of the factors considered were dietary so- 
dium intake, extracellular fluid volume, total body sodium and adrenal cortical function.

\section{REFERENCES}

1. Hollander, W., and Judson, W. E., The excretion of salt in hypertensive individuals before and during chronic drug therapy. Clin. Research Proc., 1954, $2,70$.

2. Green, D. M., Wedell, H. G., Wald, M. H., and Learned, B., The relation of water and sodium excretion to blood pressure in human subjects. Circulation, 1952, 6, 919.

3. Birchall, R., Tuthill, S. W., Jacobs, W. S., Trautman, W. J., Jr., and Findley, T., Renal excretion of water, sodium, and chloride. Comparison of responses of hypertensive patients with those of normal subjects, patients with specific adrenal or pituitary defects, and a normal subject primed with various hormones. Circulation, 1953, 7, 258.
4. Goldring, W., and Chasis, H., Hypertension and Hypertensive Disease. New York, The Commonwealth Fund, 1944.

5. Roe, J. H., Epstein, J. H., and Goldstein, N. P., A photometric method for the determination of inulin in plasma and urine. J. Biol. Chem., 1949, 178, 839.

6. Brodsky, W. A., and Graubarth, H. N., Excretion of water and electrolytes in patients with essential hypertension. J. Lab. \& Clin. Med., 1953, 41, 43.

7. Green, D. M., and Ellis, E. J., Sodium output-blood pressure relationships and their modification by treatment. Circulation, 1954, 10, 536.

8. Luetscher, J. A., Jr., and Curtis, R. H., Aldosterone : Observations on the regulation of sodium and potassium balance. Ann. Int. Med., 1955, 43, 658.

9. Burnett, C. H., The actions of ACTH and cortisone on renal function in man. Josiah Macy, Jr. Foundation, 2nd Conference on renal function, 1950, p. 106. 